\title{
ІНТЕРСУБ'ЄКТНА ВЗАЄМОДІЯ ЯК БАЛАНС СВОБОДИ ТА СТРУКТУРИ
}

Удк: 159.9.016

\section{Наконечна Марія Миколаӥвна}

Кандидат психологічних наук, дочент, докторант, Національний педагогічний університет імені М. П. Драгоманова, доцент, Ніжинський державний університет імені Миколи Гоголя, м. Ніжин (Україна)

\begin{abstract}
Анотація. У статті аналізується інтерсуб'єктна взаємодія в ї̈ широкій та вузькій інтерпретаиії. Досліджується співвідношення свободи та структури в інтерсуб'єктній взаємодії людей. Інтерсуб'єктна взаємодія розуміється як простір взаємного розвитку та зростання рівня суб'єктності, щу виражається в підвищенні активності, рефлексивності, креативності та авторства. Вивчаються можливості співвіднесення екзистенційного, культурно-історичного, суб'єктного та вчинкового підходів стосовно інтерсуб'єктної взаємодії. Виявляється потенціал залучення поняття рефлексї̈ до пояснення особливостей інтерсуб 'єктної взаємодії людей. Обтрунтовується, щуо взаємодія стає інтерсуб'єктною за умови відкритості у міжлюдських взаєминах. Викладені результати пілотажного дослідження розроблюваного опитувальника інтерсуб'єктності (М. М. Наконечна). Результати засвідчили достатні показники придатності методики (альфа Кронбаха $\alpha=0,777)$. Здійснений розподіл даних за рівнями розвитку інтерсуб 'єктності (високий, середній, низький).
\end{abstract}

Ключові слова: інтерсуб 'єктність, взаємодія, свобода, структура, рефлексія.

Постановка проблеми. Інтерсуб'єктна взаємодія - це важливий компонент процесу становлення суб'єктності людини. Внаслідок інтерсуб’єктної взаємодії як особливої форми людської комунікації зростає рівень суб'єктності учасників інтеракції, що може проявлятися в збільшенні рівня креативності, відповідальності, рефлексивності, творчості. Прояви інтерсуб'єктної взаємодії як взаєморозвиваль- ної форми стосунків можуть спостерігатися в актах дружби, допомоги, піклування, діалогу, вислуховування тощо. Інтерсуб'єктність у взаємодії проявляється в тому, що у учасників такої взаємодії з'являється натхнення, ніби «виростають крила», розкривається творчий та особистісний потенціал. Людина під впливом інтерсуб'єктних стосунків прагне стати кращою, ніж була, пробує здійснити певні 
значущі сенси та задуми, намагається самореалізуватися. I оскільки інтерсуб' єктна взаємодія $є$ формою високогуманних, конструктивних взаємин, вивчення цього феномену з точки зору психологічної науки є дуже актуальним та значущим.

Актуальною є проблема розгляду інтерсуб'єктної взаємодії як балансу свободи та структурованості, адже ці поняття виводять поняття інтерсуб'єктності на перетин культурно-історичного, екзистенційного, суб'єктного та вчинкового підходів.

\section{Аналіз останніх досліджень та публі-} кацій. Український дослідник В. Васютинський [4] розглядає інтерсуб'єктну взаємодію як у цілому інтеракції між людьми. Наша концепція інтерсуб'єктності пропонує порівняно з цим звужений розгляд поняття, фокусуючись на інтерсуб'єктній взаємодії як формі взаємного збагачення та розвитку завдяки певним особливим актам спілкування, яке збільшує рівень суб'єктності учасників.

$$
\text { У дисертаційному дослідженні }
$$

В. В. Гобунової «Психологія командотворення: ціннісно-рольова парадигма» зазначається: «Успіх командної праці пов’язують, насамперед, із «скоординованою позитивною синергією» - здатністю учасників до високопродуктивної діяльності, за якої спільний результат значно вищий за індивідуальний чи їхню суму» [5, с. 1]. Інтерсуб'єктну взаємодію також можна пояснити за допомогою концепту «скоординованої позитивної синергії», адже такий різновид взаємодії пов'язаний як із зростанням зовнішньої продуктивності, так і з розвитком внутрішніх ресурсів суб'єктносTi.

Г. В. Дьяконов наголошує на тому, що інтерсуб'єктні методи дослідження, які розуміються автором як специфічні для вивчення діалогічних аспектів існування особистості, $\epsilon$ в принципі надзвичайно складними для реалізації. Дослідник зазначає: «...дуже важко або взагалі неможливо створити загальний і універсальний психологічний тест діалогу (або діалогічності особистості ), проте, можна сконструювати багато різноманітних методів діалогічного дослідження, що відображають різні сторони «людино-людської» реальності» [2, с. 5]. Г. В. Дьяконов пропонує дві психодіагностичні методики - інтерсуб'єктнодіалогічна методика «Поле почуттів» та інтерсуб'єктно-діалогічний опитувальник «Надія». Інтерсуб'єктність розуміється автором як сторона діалогічної форми комунікації.

Д. О. Леонтьєв пов'язує можливості взаєморозвивальної взаємодії з поняттям особистісного потенціалу Автор писав: «... людина, яка має високий ОП (особистісний потенціал. - М.Н.), у різних ситуаціях, в які вона потрапляє - у горі та в радості, в міжособистісних відносинах та у діловій активності буде діяти так, щоб у кожний наступний момент іï ситуація ставала краще 3 точки зору критеріїв бажаного, на які вона орієнтується (i які також можуть змінюватися)» [6]. Така точ- 
ка зору задає динамічні орієнтири в розгляді особистості, яка часто до цього розглядалася статично, поза реальним процесом розвитку (маються на увазі передусім емпіричні дослідження, а не постулювання принципу розвитку в теоретичних міркуваннях). Як можна припустити, особистісний потенціал значно впливає на інтерсуб'єктну взаємодію, фактично уможливлюючи іï взаєморозвивальний характер щодо учасників інтеракції.

Постановка завдання. На основі викладеного можна сформулювати завдання дослідження, яке полягає в теоретичному аналізі інтерсуб'єктної взаємодії та викладі результатів пілотажного дослідження опитувальника інтерсуб'єктності.

Виклад основного матеріалу дослідження. Свобода і структура часто протистоять одна одній у міжособистісних відносинах. Інтерсуб'єктність 3'являється там, де виникає баланс між свободою та структурою у відносинах. Тобто людина водночас усвідомлює певні рамки, границі і обмеження та, з іншого боку, дозволяє виявлятися свободі, автентичності, творчості, вільному самовиявленню - як своїм, так і іншої людини. Інтерсуб'єктність підтримує баланс свободи та структури, мінливості та стабільності, розвитку та сталих особливостей. Розуміння та переживання того, що у відносинах 3 іншою людиною я можу просто бути, створює простір інтерсуб'єктності. Взаємодія між людьми, яка грунтується на визнанні, рівності, паритетності, на повазі та прислуханні один до одного, створює потужний потенціал розвитку та саморозвитку і тим самим уможливлює інтерсуб'єктні відносини.

Інтерсуб'єктний характер взаєморозвивальної взаємодії підкреслює, що людина існує і розвивається в різних системах відносин з іншими людьми. Наприклад, за Л. С. Виготським, пам'ять як вища психічна функція - це відпочатково інтерпсихологічна функція, розподілена між людьми (дорослим та дитиною). I тільки в процесі розвитку стає можливим оволодіти цією функцією, і вона з інтерпсихологічної стає інтрапсихологічною, моєю, особистісною. А в динаміці, в розвитку людина розвивається як цілісність у взаємодії з іншими людьми.

У роботі «Історія розвитку вищих психічних функцій» Л. С. Виготський писав: «Культурний розвиток якоїсь функції, у тому числі й уваги, полягає в тому, що в процесі спільного життя та діяльності суспільна людина виробляє низку штучних стимулів, знаків. 3 ïх допомогою спрямовується суспільна поведінка особистості, вони ж стають основним засобом, за допомогою якого особистість оволодіває власними процесами поведінки» [3; с. 207]. Отже, інтерпсихологічне, інтерсуб'єктне, міжособистісне стає тим полем, у якому народжуються інтрапсихологічні структури та функції. I вже після цього, досягши певного рівня розвитку суб'єктності, людина може виражати, вивільняти, втілювати власну інтрасуб'єктність у відносинах інтерсуб'єктності. 
Взаємодія інтер- та інтрасуб'єктних процесів діалектично складна та суперечлива. Неможливо виділити окрему точку відліку - в рівній мірі правильним буде сказати, і що інтрасуб' єктне народжується через інтерсуб'єктні відносини, і що інтерсуб'єктна взаємодія потребує для свого повноцінного вираження i розвитку розвиненої інтрасуб'єктності. Тому ми не можемо виявити інтерсуб'єктність у іiі вищих проявах в молодшому шкільному віці чи раніше*, адже для розвиненої інтерсуб'єктності повинна бути певна сформованість суб'єктних якостей індивіда, його внутрішньої суб'єктності.

М.М. Бахтін писав: «Свобода та активність створюють ритм для невільного (етично) та пасивного буття. Творець є вільним та активним, а те, що створюється, є невільним та пасивним» [1, с. 105]. Отже, автор протиставляє сводобу та ритмованість, структурованість, рамки, межі. Водночас слід розуміти, що єдність творця та того, що створюється, активності та пасивності, свободи та ритму $є$ діалектичною єдністю суперечностей. Одне не може існувати без іншого і припускає самим своїм існуванням інший модус буття. Стосовно інтерсуб'єктної взаємодії це означає, що взаєморозвивальний характер інтерсуб'єктності припускає існування і активних, і пасивних форм інтеракцій, і вільних, і ритмізованих способів самовиявлення.

Г. Олпорт у коментарях до збірника
«Екзистенційна психологія» (за ред. Р. Мея) зазначав: «Моя думка полягає в тому, що психологія повинна робити розрізнення між життям, де $є$ реальна екзистенційна наповненість, і життям, де це є явною маскою, за якою приховується гуркіт безсвідомого» [7]. Інтерсуб'єктна взаємодія допомагає прожити, пережити, означити та осмислити життя, яке має глибокий зміст та екзистенційні виміри. Інтерсуб'єктність, яку ми розуміємо як досвід взаєморозвиваючої та взаємозбагачуючої взаємодії, напонює життя людини вищими екзистенційними переживаннями, дотиком до творчості, свободи, гармонії та щастя.

Рефлексія у міжсуб'єктній взаємодії виступає тим важливим метакогнітивним процесом, який інтегрує, структурує та узагальнює досвід і водночас робить людину чутливою та відкритою до нового. За допомогою механізму рефлексивного усвідомлення інтерсуб'єктна взаємодія створює простір для розвитку особистості та індивідуальності людини. Рефлексія, сама будучи характеристикою досить високого рівня психічного розвитку, $є$ водночас чинником подальшого особистісного зростання людини. Через рефлексію людина може ставитися до себе та свого власного досвіду «нібито зі сторони», асимілюючи те, що потрібно асимілювати, та відкидаючи те, що потрібно відкинути.

Рефлексія уможливлює усвідомлення цінності та окремих конкретних характерис-

* І Із усної розмови з доктором психологічних наук, професором М.В. Папучею. 
тик інтерсуб'єктної взаємодії. Рефлексивна людина більш чутлива до потреб власних та інтересів інших людей. За допомогою рефлексії людина може глибше, об'ємніше, яскравіше, фундаментальніше пізнати себе - зокрема, через пізнання інших людей, через розуміння того, що моє ставлення до інших є важливою інформацією для мене та про мене.

Рефлексія у інтерсуб'єктній взаємодії є важливим механізмом взаємного розвитку та платформою для пізнання себе та інших в просторі міжособистісних відносин. Рефлексія $€$ тим вищим рівнем усвідомлення, за допомогою якого стають можливі якісні психологічні трансформації в індивідуальному житті людини.

Взаємодія стає інтерсуб'єктною, коли люди відкриваються один назустріч одному, означують особистісні сенси та осмислють значущі змісти. Одним із результатів такої взаємодії стає розвиток всіх учасників, включених в інтерсуб'єктне спілкування.

В історії психології ми можемо спостерігати поступове сходження до категорії «інтерсуб'єктності» - від «психології окремого індивіда» в біхевіористичних, психоаналітичних, психометричних концепціях кінця XIX - початку XX століття до «людини-всвіті», людини в просторі відносин з іншими людьми другої половини XX - початку XXI століття.

3 точки зору категорії інтерсуб'єктності в психоаналізі маємо справу з ситуацією вивчення відносин людини 3 найближчими значущими іншими. Явища трансферу та контртрансферу описують те, що людина нібито переносить своє ставлення до одного 3 батьків на психотерапевта, а психотерапевт, відповідно, теж може мати певні почуття до пацієнта, перенесені із відносин із значущими іншими.

Видатний психолог ХХ ст. С.Л. Рубінштейн зазначав: «Специфіка людського існування полягає в мірі самовизначення та визначення іншим» [8, с. 303]. У цій тезі підкреслюється нероздільність існування людини та інших людей. У концепті інтерсуб'єктності можемо бачити винесений назовні процес людського розвитку, який здійснюється як комунікація індивіда з іншими. Інакше кажучи, інтерсуб'єктна взаємодія є таким різновидом інтеракції між людьми, який процесуально та результативно є розвитком. У динаміці інтерсуб'єктної взаємодії здійснюється розвиток людини та її суб'єктних якостей, а результатом інтерсуб'єктної комунікації є зростання рівня суб'єктності учасників.

Важливим є поєднання різних підходів у психологічному пізнанні. Плідний приклад поєднання суб'єктного та вчинкового підходів дає український науковець В.О. Татенко, який писав: «Якщо поняття «суб’єктність» несе в собі, з одного боку, наукове знання про онтопсихологічний проект людського буття, а 3 іншого - фіксує такі сутнісні ознак людської активності, як автономність, креативність, ці- 
лісність і гармонійність, орієнтує в напрямі пошуку внутрішніх джерел та рушійших сил розвитку людської істоти, підкреслює іï авторське право, спроможність починати причинний ряд із самої себе, а значить, - нести персональну відповідальність за вчинене і скоєне, то поняття «вчинковість» означає індивідуально-неповторний, ціннісно-смисловий, культурно-особистісний вектори суб'єктної активності людини в їхньому сутнісному вимірі» $[9$, с. 9]. Поєднання суб'єктного та вчинкового підходів дає змогу наблизитися до реальної, конкретної особистості в єдності їі активності та відповідальності, унікальності та вершинних проявів. Водночас слід зазначити, що поєднання різних підходів може бути еклектичним, але це продуктивна, здорова еклектика, за Г. Олпортом, еклектика, яка дає шлях інтеграції та цілісному пізнанню складних психологічних явищ. Стосовно інтерсуб'єктності це означає, що вивчення розподілених між людьми функцій уможливлює розуміння не тільки міжособистнісних відносин, але й інтрапсихічних функцій, які, згідно з методологією Л.С. Виготського, колись були функціями інтерпсихічними. Інакше кажучи, врахування суб'єктної та вчинкової інваріантів людського розвитку дозволяє з'ясувати психологічні механізми функціонування та становлення людської особистості.

3 метою уможливлення емпіричних до- сліджень в галузі інтерсуб'єктності ми розпочали процес створення та стандартизації методики дослідження інтерсуб'єктності (М.M. Наконечна). Методика $\epsilon$ опитувальником, який містить 16 пунктів, на кожен 3 яких можна дати відповідь за п'яти-бальною шкалою Лайкерта - від «повністю згоден/згодна» до «повністю не згоден/не згодна». Опитувальник розроблений українською мовою.

Методика дослідження інтерсуб'єктності (М.М. Наконечна) призначена для психологічної діагностики інтерсуб'єктності як інтегральної властивості взаємодії між людьми, яка проявляється в комунікабельності, прагненні спілкуватися та взаємодіяти 3 іншими, позитивних емоціях в процесі спілкування.

Пілотажне дослідження було проведене на вибірці осіб юнацького віку - учнів Ніжинського обласного педагогічного ліцею Чернігівської обласної ради та студентів спеціальностей «Психологія» та «Практична психологія» (III курс) Ніжинського державного університету імені Миколи Гоголя*. У пілотажному дослідженні взяло участь 93 особи.

Першим кроком в стандартизації тесту стало обрахування статистик придатності. Альфа Кронбаха для досліджуваної вибірки становить $\alpha=0,777$, що $є$ прийнятним рівнем (вище 0,7). Коефіцієнт Спірмена-Брауна становить 0,835 , що є хорошим (вище 0,8 ) рівнем придатності тесту. Коефіцієнт полповинного

\footnotetext{
* Автор висловлює вдячність С. Р. Міняйло, практичному психологу Ніжинського обласного педагогічного ліцею Чернігівської обласної ради, асистенту Ніжинського державного університету імені Миколи Гоголя, за допомогу у зборі даних.
} 
розщеплення Гутмана становить 835 , що свідчить про хороший (вище 0,8 ) рівень придатності тесту.

Другим кроком стало обрахування норм тесту, що було здійснене лише у першому наближенні. Планується перерахування норм тесту на основній вибірці (не менш ніж 500 осіб). Для обрахування норм тесту ми використувували середнє арифметичне та стандартне відхилення.

Середнє арифметичне для нашої вибірки в 93 особи становить 68,02, стандартне відхилення - 6,82, медіана - 69, мода - 70 . Середнє, медіана та мода мають дуже близькі значення, що свідчить про те, що вибірка може бути досліджена як близька до нормального розподілу.

Результати обрахування норм тесту із їх змістовною інтерпретацією наведені нижче.

Високий рівень інтерсуб'єктності (7380 балів) проявляється в тому, що людина прагне взаємодіяти, спілкуватися 3 іншими людьми. Процес взаємодії з іншими приносить позитивні емоції, радість і натхнення.

Середній рівень інтерсуб'єктності (6472 бали) проявляється в тому, що людина проявляє помірне прагнення спілкуватися з іншими. Процес спілкування з іншими проносить здебільшого позитивні емоції.

Низький рівень інтерсуб'єктності (1663 бали) проявляється у тому, що людина проявляє низький рівень прагнення спілкуватися та взаємодіяти 3 іншими. Процес взаємодії приносить мало позитивних емоцій, радості та натхнення.

Пілотажне дослідження засвідчило, що за основними показниками розроблювана методика $є$ придатною, але в той же час необхідне основне дослідження з вибіркою в не менш ніж 500 осіб, щоб стандартизувати методику.

\section{Висновки 3 проведеного досліджен-}

ня. 3 наведеного вище можна зробити наступні висновки.

Інтерсуб'єктна взаємодія може бути розглянута у широкому розумінні - як будьяка взаємодія між людьми, та у вузькому розумінні - як така особлива форма взаємодії, яка сприяє розвитку суб'єктності учасників, що проявляється у зростанні відповідальності, активності, рефлексивності, авторства та креативності. Взаєморозвивальний характер інтерсуб'єктної взаємодії підкреслюється характеристиками свободи, структурованості та рефлексії, які у своєму взаємозв'язку визначають перспективи суб'єктного становлення людини.

Розроблювана методика дослідження інтерсуб'єктності на етапі пілотажного дослідження показала достатні показники придатності і може стати надійним психодіагностичним україномовним інструментом.

Отже, інтерсуб'єктна взаємодія є балансом свободи та структури, де інтрапсихічні смисли опредметнюються та набувають інтрапсихічних значень, внутрішне стає змістом для міжособистісної комунікації, а людина 
стає вільною, залишаючись при цьому в рамках та межах власного життя.

Перспективою подальших наукових розвідок $є$ стандартизація методики дослідження інтерсуб'єктності на репрезентативній вибірці та поглиблений теоретичний аналіз поняття інтерсуб'єктності в психології.

\section{Перелік використаних джерел:}

1. Бахтин М. М. Эстетика словесного творчества / М.М. Бахтин. - М.: Искусство, 1979. - 424 с.

2. Дьяконов $Г$. В. Інтерсуб'єктні методи оцінювання психології особистості. Навчальний посібник для вищої школи / Г.В. Дьяконов. - Кіровоград: Лисенко В.Ф., 2012. $-36 \mathrm{c}$.

3. Выготский Л. С. Собрание сочинений: В 6-ти т. Т.3. Проблемы развития психики / Л.С. Выготский. Под ред. А. М. Матюшкина. - М.: Педагогика, 1983. - 368 $\mathrm{c}$, ил.

4. Васютинський В. Інтеракційна психологія влади / В. Васютинський. - К., 2005. - 492 с.

5. Горбунова В. В. Психологія командотворення: ціннісно-рольова парадигма / В.В. Горбунова. - Автореф. Дис. ... доктора психол. наук. - К., 2014. - 28 с.

6. Леонтьев Д. А. Промежуточные итоги: от идеи к концепции, от переменных к системной модели, от вопросов к новым вопросам / Д.А. Леонтьев // Личностный потенциал: структура и диагностика / Под ред. Д.А. Леонтьева. - М.: Смысл, 2011. - 675 с.

7. Олпорт Г. Комментарии к предыдущим главам / Г. Олпорт // Экзистенциальная психология. Под редакцией Ролло Мэя. Перевод М.Занадворова и Ю.Овчинниковой. - М.: Апрель Пресс \& ЭКСМОПресс, 2001.Терминологическая правка В.Данченко. K.: PSYLIB, 2005. Режим доступу: $\underline{\text { http:// }}$ psylib.ukrweb.net/books/meyro04/txt06.htm

8. Рубинштейн С. Л. Бытие и сознание. Человек и мир /
С.Л. Рубинштейн. - СПб.: Питер, 2003. - С. 282-426.

9. Татенко В. О. Від редактора / В.О. Татенко // Людина. Суб’єкт. Вчинок: Філософсько-психологічні студії / За заг. ред. В.О. Татенка. - К.: Либідь, 2006. - С. 6-11.

\section{References (Transliteration):}

1. Bahtin M. M. Estetika slovesnogo tvorchestva / M.M. Bahtin. - M.: Iskusstvo, 1979. - 424 s.

2. Dyakonov G. V. Intersub'EktnI metodi otsInyuvannya psihologIYi osobistostI. Navchalniy posIbnik dlya vischoYi shkoli / G.V. Dyakonov. - Kirovograd: Lisenko V.F., 2012. $-36 \mathrm{~s}$.

3. Vyigotskiy L. S. Sobranie sochineniy: V 6-ti t. T.Z. Problemyi razvitiya psihiki / L.S. Vyigotskiy. Pod red. A. M. Matyushkina. - M.: Pedagogika, 1983. - 368 s , il.

4. Vasyutinskiy $V$. InteraktsIyna psihologIya vladi / V. Vasyutinskiy. - K., 2005. - 492 s.

5. Gorbunova $\quad V . \quad V$. PsihologIya komandotvorennya: tsInnIsno-rolova paradigma / V.V. Gorbunova. - Avtoref. Dis. ... doktora psihol. Nauk. - K., 2014. - 28 s.

6. Leontev D. A. Promezhutochnyie itogi: ot idei k kontseptsii, ot peremennyih $\mathrm{k}$ sistemnoy modeli, ot voprosov $\mathrm{k}$ novyim voprosam / D.A. Leontev // Lichnostnyiy potentsial: struktura i diagnostika / Pod red. D.A. Leonteva. - M.: Smyisl, 2011. - 675 s.

7. Olport G. Kommentarii k predyiduschim glavam / G. Olport // Ekzistentsialnaya psihologiya. Pod redaktsiey Rollo Meya. Perevod M.Zanadvorova i Yu.Ovchinnikovoy. - M.: Aprel Press \& EKSMO-Press, 2001.Terminologicheskaya pravka V.Danchenko. - K.: PSYLIB, 2005. Rezhim dostupu: http://psylib.ukrweb.net/ books/meyro04/txt06.htm

8. Rubinshteyn S. L. Byitie i soznanie. Chelovek i mir / S.L. Rubinshteyn. - SPb.: Piter, 2003. - S. 282-426.

9. Tatenko V. O. Vid redaktora / V.O. Tatenko // Lyudina. Sub'Ekt. Vchinok: Filosofsko-psihologIchnI studIYi / Za zag. Red. V.O. Tatenka. - K.: LibId, 2006. - S. 6-11. 


\section{Nakonechna Maria}

Ph.D. in Psychology, associate professor, doctorate student, M. P. Dragomanov National Pedagogical University, associate professor, Nizhyn Mykola Gogol State University, Nizhyn (Ukraine)

\section{INTERSUBJECT INTERACTION AS A BALANCE OF FREEDOM AND STRUCTURE}

\section{ABSTRACT}

The intersubject interaction is analyzed in its broad and narrow interpretation within the article. Freedom and structure correlation in intersubject human interaction is investigated. Intersubject interaction is viewed as a space of mutual development and agental growth, which are explicated via the increase of activity, reflexivity, creativity and authorship. Intersubject interaction as a special form of human communication stimulates the agental rate of interaction participants to grow, which can result in the increase of creativity, responsibility and reflexivity. The developments of intersubject interaction as codevelopmental relations may occur in acts of friendship, help, care, dialogue, listening to the others and so on.

The concept of intersubjectness makes a clear display of exteriorized process of human development, which implements as a person's communication with others. In other words, intersubject interaction is such interpersonal interactions type, which is the development in its process and results. The development of a person and his/her agental traits is performed within the intersubject interaction dynamics. The result of intersubject communication is the growth of the communication participants' agency rate.

The possibilities to correlate culturalhistorical, existential, subject and deed-subject approaches are studied in relation to intersubject interaction. The possibility to include the concept of reflexion into the explanative model of human intersubject interaction is explored. It is argued that interaction becomes intersubject upon condition of openness in human relations.

The results of pilot survey of the intersubject questionnaire by M.M. Nakonechna are presented. The intersubject questionnaire by M.M. Nakonechna is created for the psychological diagnostics of intersubjectness as an integral feature of human interaction that explicates in communicative skills, the tendency to communicate and to interact with others, positive emotions in communication process. The results showed the sufficient figures of the technique's validity (Cronbach's alpha $\alpha=0,777$ ). The data is grouped according to the intersubjectness development levels (high, medium, low).

Key words: intersubjectness, interaction, freedom, structure, reflexion.

\section{Наконечная Мария Николаевна}

Кандидат психологических наук, дочент, докторант, Наииональный педагогический университет имени Н. П. Драгоманова, доиент, Нежинский государственный университет имени Н. В. Гоголя, г. Нежин (Украина)

\section{ИНТЕРСУБЪЕКТНОЕ ВЗАИМОДЕЙ- СТВИЕ КАК БАЛАНС СВОБОДЫ И СТРУКТУРЫ}


Аннотация. В статье анализируется интерсубъектное взаимодействие в его широкой и узкой интерпретации. Исследуется соотношение свободы и структуры в интерсубъектном взаимодействии людей. Интерсубъектное взаимодействие понимается как пространство взаимного развития и возрастания субъектности, что выражается в повышении активности, рефлексивности, креативности и авторства. Вследствие интерсубъектного взаимодействия как особой формы человеческой коммуникации возрастает уровень субъектности участников интеракции, что может проявляться в увеличении уровня креативности, ответственности, рефлексивности, творчества. Проявления интерсубъектного взаимодействия как взаиморазвивающей формы отношений могут наблюдаться в актах дружбы, помощи, заботы, диалога, выслушивания других и т.д.

В концепте интерсубъектности можно увидеть вынесенный вовне процесс человеческого развития, осуществляющийся как коммуникация индивида с другими. Иными словами, интерсубъектное взаимодействие является такой разновидностью интеракции между людьми, который процессуально и результативно является развитием. В динамике интерсубъектного взаимодействия осуществляется развитие человека и его субъектных качеств, а результатом интерсубъектной коммуникации является возрастание уровня субъектности участников.
Изучаются возможности соотнесения культурно-исторического, экзистенциального, субъектного и последовательного подходов относительно интерсубъектного взаимодействия. Выявляется потенциал привлечения понятия рефлексии к объяснению особенностей интерсубъектного взаимодействия людей. Обосновывается, что взаимодействие становится интерсубъектным при условии открытости в межчеловеческих отношениях.

Изложены результаты пилотажного исследования разрабатываемого опросника интерсубъектности (М. Н. Наконечная). Методика исследования интерсубъектности (М. Н. Наконечная) предназначена для психологической диагностики интерсубъектности как интегрального качества взаимодействия между людьми, проявляющегося в коммуникабельности, стремлении общаться и взаимодействовать с другими, положительных эмоциях в процессе общения. Результаты засвидетельствовали достаточные показатели пригодности методики (альфа Кронбаха $\alpha=0,777$ ). Осуществлено распределение данных по уровням развития интерсубъектности (высокий, средний, низкий).

Ключевые слова: интерсубъектность, взаимодействие, свобода, структура, рефлексия.

Дата отримання статті: 01.12.2017 Дата рекомендації до друку: 19.12.2017 